\title{
Studies on Oxalate-decomposing Bacteria Isolated from Alocasia Plants
}

\author{
by Kazuko YARA* and Shoichiro USAMI**
}

\author{
Received December 4, 1967
}

\begin{abstract}
Three strains of oxalate-decomposing bacteria, "Pink", " Red" and "Yellow", were isolated from the petiole of Alocasia macrorrhiza. The oxalate metabolism was studied with the intact cells and the cell-free extracts.

Oxalate was oxidized by cell-free extract of bacterial cells ("White") when CoA, TPP, ATP, $\mathrm{Mg}^{++}$and acetate had been added as cofactors. From this finding, a mechanism including an intermediary formation of formate through decarboxylation of oxalate was postulated in accord with the previous knowledge of bacterial oxalate metabolism.

Exhaustive incubation experiments of oxalate with intact bacterial cells suggest that some oxalate metabolism other than complete oxidation may be functioning at the same time in the bacterial cells.

The activity of oxalate oxidation in these bacteria increased adaptively on incubation with oxalate.
\end{abstract}

Large quantities of oxalate are often found in higher plants. Oxalate, however, does not generally accumulate in fertile soil to an extent injurious to plant growth. Bassalik $^{1)}$ who isolated several oxalate-decomposing bacteria from soil, assumed that these bacteria must participate in the rapid disappearance of oxalate from soil. To date several microorganisms, which are able to grow on a medium containing only oxalate as a sole carbon source, have been isolated from soil ${ }^{2,3)}$. And the metabolism of oxalate by these organisms has been investigated either with intact cells or with cell-free extracts.

Expecting the presence of oxalate-decomposing microorganisms living upon higherplant bodies which are abundant in oxalate, attempts were made to isolate the microorganisms from the juice of petiole of Alocasia macrorrhiza. Consequently, three strains of oxalate-decomposing bacteria were isolated. In this paper, the results of the studies on some properties of oxalate metabolism in the bacteria are reported.

\section{Materials and Methods}

Isolation: The plant, Alocasia macrorrhiza collected at the vicinity of University of the Ryukyus, was used as the material. Care was taken to employ the fresh leaves showing no symptom of disease. The petioles of Alocasia macrorrhiza cut in appro-

* Department of Biology, Division of Sciences and Engineerings, University of the Ryukyus, Naha, Okinawa.

** Department of Botany, Faculty of Science, Hokkaido University, Sapporo, Japan. 
priate length were surface-sterilized in the Bunsen flame and carefully crushed in a sterile petri-dish with the aid of a sterile scalpel and then smeared on the oxalate agar plates similar to that of Bhat and Barker"). After a few day's incubation, the colonies of oxalate-decomposing bacteria could easily be recognized by the formation of a clear zone or halo around each colony as a result of the disappearance of the calcium oxalate crystals. Purification was completed after repeating several transfers from a single colony surrounded by clear zone to other plates.

Growth conditions: The bacteria were cultivated for $17-20$ hours at $30^{\circ}$ by vigorous shaking in $300-\mathrm{m} l$. Erlenmeyer flasks containing $100 \mathrm{~m} l$. of medium, which is composed of inorganic salts, ammonium sulfate and oxalate. Then the cells were collected and washed twice with $0.9 \%$ saline by centrifugation. The cell paste was frozen for enzyme preparation or resuspended in the saline for experiments with intact cells.

Enzyme preparation: Partially purified enzyme preparations were obtained from the bacteria by the methods of Jakoby et $a l^{5}$.

Properties of oxidation: Oxygen uptake and $\mathrm{RQ}$ values were measured by the conventional manometric methods. For the determination of $\mathrm{RQ}, \mathrm{CO}_{2}$ was released from the liquid in manometer cup by adding sulfuric acid contained in side-arm. The Clark oxygen electrode was also used to detect a minute oxygen consumption either by intact cells or by soluble enzyme system (Fig. 4). Decomposition of oxalate was estimated by measuring the changes in optical density at $220 \mathrm{~m} \mu^{6}$.

\section{Results}

Isolation and description of the bacteria. Three strains of oxalate-decomposing bacteria were isolated by the plating technique. Owing to their distinctive color of colonies, they were tentatively designated as "Pink", "Red" and "Yellow". All the three kinds of bacteria were found to be small, motile, aerobic, Gram-negative rods. After 48 hours "Pink" grew on the oxalate agar to form small colonies, which were moist, raised and had entire edges. The colonies grew slowly on further incubation and reached a maximum diameter of $1 \mathrm{~mm}$ in about 4 days. "Red" was similar in its appearance and behavior to the former except that the colonies were dry and blood-red pigmented. The colonies of "Yellow" were similar to but larger than those of "Pink".

For the enrichment culture, Bhat and Barker's medium ${ }^{4)}$ was used with the modification of $\mathrm{pH}$ and the concentration of oxalate and yeast extract. Optimum conditions for each bacterium were as follows: for "Pink", $\mathrm{pH} 6.0$, oxalate $0.1 \%$, yeast extract $0.5 \%$; for "Red", 6.0, 0.25\%, 0.25\%; for "Yellow", 7.0, 0.25\%, 0.5\%. In the liquid media, "Pink" grew characteristically as a film on the bottom of the flask, "Red" dispersed uniformly, and "Yellow" formed many clumps, leaving the liquid clear in cultures older than 20 hours. The growth of "Yellow" was rapid, but the other two grew slowly.

Pink, red and yellow pigments of each bacterium were extracted in 80 per cent ethanol and the dried extracts were soluble in water. All of the pigment solutions showed blue fluorescence but no absorption spectrum of flavin was detected. Most of experiments reported in this paper were done with "Pink", as the occurrence of this 
bacterium in the plant sample was more frequent than others.

Accidentally, another oxalate-decomposing bacterium was isolated from the liquid medium left for several days in refrigerator without sterilizing. The bacterium, designated as "White", formed translucent pin-point colonies, and appeared to be a motile, aerobic, Gram-negative short rod. The isolation was reproducible. The properties of this air-born oxalate-decomposing bacterium was reported additionally in this paper.

Other plants were also examined. Oxalate-decomposing bacteria could be isolated from the following plant materials; Nicotiana tabacum (leaf and stem), Rumex japonicum, Beta vulgaris var. Cicla, Spinacia oleracea, Medicago lupulina, and Oxalis corymbosa (leaf).

Properties of oxidation. The optimum $\mathrm{pH}$ for oxidation of formate by the three bacteria, "Pink", "Red" and "Yellow", were almost similar to that of oxalate. The rate of oxidation of formate was much higher than that of oxalate. The airborn bacterium, "White", showed different behavior: the rates of oxidation for both substrates were similar, and yet, the optimum $\mathrm{pH}$ values were distinct; 6.0 for formate and 8.0 for oxalate (Fig. 1). Oxidations of oxalate and formate were compared, because formate seemed to be an intermediate of oxalate metabolism. The RQ value for oxalate oxidation by "Yellow" is in accordance with the theoretical value of 4 for complete oxidation of oxalate. The RQ values for formate are approximately

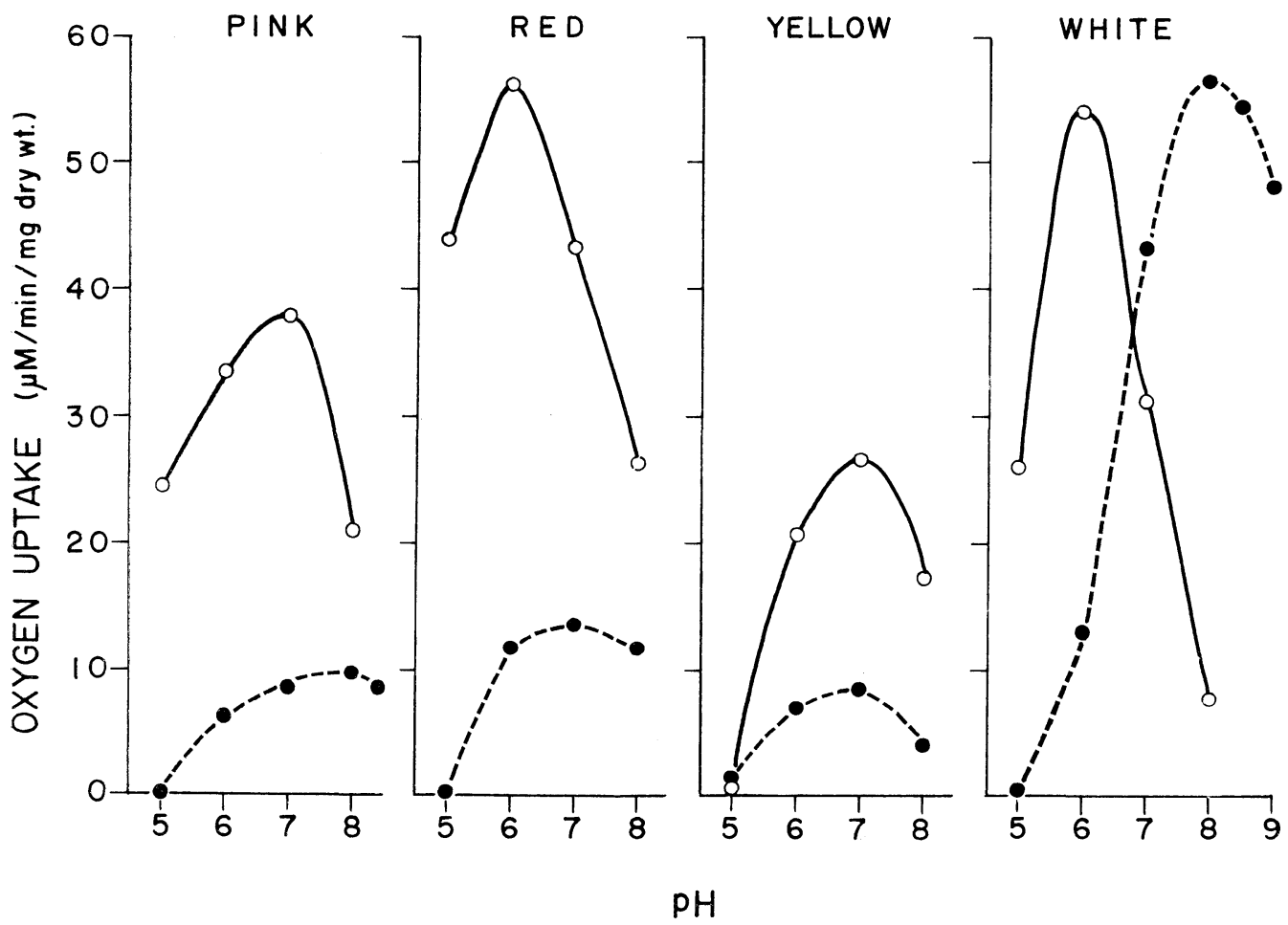

Fig. 1. Effects of $\mathrm{pH}$ on oxidation of oxalate and formate by cells of " Pink", " Red ", "Yellow" and "White". M/20 buffer, acetate $\mathrm{pH}$ 5.0, phosphate $\mathrm{pH}$ 6.0-8.0, Tris $\mathrm{pH}$ 8.0-8.4; $\mathrm{M} / 60$ substrates; 2-3 $\mathrm{mg}$ dry weight of cells; $30^{\circ}$. $\bigcirc \longrightarrow$ formate, 
two in all four bacteria and they also accord with the theoretical value (Table 1).

The effects of inhibitors on the oxidation of oxalate and formate by the washed cells of "Pink" were studied. Nitrate", acriflavin and chlorpromazine, which are specific inhibitors for flavin enzymes, had no effect. It seems that flavin enzyme is not involved in the oxidation of oxalate. On the other hand, $\mathrm{KCN}, \mathrm{NH}_{2} \mathrm{OH}$ and $\mathrm{NaN}_{3}$ inhibited the oxidation of oxalate and formate equally. The effect of MIA (monoiodoacetate), however, was suppressive on oxalate oxidation and rather stimulative for formate oxidation (Table 2).

The oxidative activities of washed cells of "Pink" grown in the oxalate medium were examined for a number of organic acids, amino acids, sugars and alcohol (Table 3 ). It was confirmed that the washed cells were able to oxidize all members of TCA cycle. The rates of oxidation of succinate, oxaloacetate and ethanol are higher than that of oxalate. Acetate, fumarate, malate and pyruvate were oxidized at about the same rate as oxalate. Citrate, $\alpha$-ketoglutarate, malonate, glycine, aspartate, L-glutamate, propionate and glycolate were poorly oxidized, and sugars, DL-alanine, DLvaline, L-serine, L-lysine, L-leucine, DL-threonine, and L-tryptophan were not oxidized at all. Whether the substrates, which are oxidized only poorly or not at all, are

Table 1. Respiratory quotient of oxalate and formate oxidation by bacterial cells.

\begin{tabular}{l|c|c|c|c|c}
\hline \multicolumn{2}{|c|}{ Strains } & "Pink & "Red & "Yellow & "White " \\
\multicolumn{3}{c|}{ Substrates } & & & \\
\hline \multirow{3}{*}{ Oxalate } & $\mathrm{Qo}_{2}$ & 80 & 90 & 50 & 160 \\
& $\mathrm{RQ}$ & 6.2 & 9.1 & 4.3 & 2.5 \\
\hline \multirow{3}{*}{ Formate } & $\mathrm{Qo}_{2}$ & 200 & 230 & 110 & 100 \\
& $\mathrm{RQ}$ & 2.1 & 2.3 & 2.3 & 2.2 \\
\hline
\end{tabular}

Conditions: $\mathrm{M} / 20$ phosphate buffer, optimum $\mathrm{pH}$ for each substrate (Fig. 1) ; M/60 substrate; $2-3 \mathrm{mg}$ dry weight of cells ; $30^{\circ}$.

Table 2. Effects of inhibitors on oxidation of oxalate and formate.

\begin{tabular}{|c|c|c|c|}
\hline Inhibitors & Concentration (M) & $\begin{array}{l}\% \text { Inhibition of } \\
\text { Oxalate }\end{array}$ & $\begin{array}{c}\text { oxidation of } \\
\text { Formate }\end{array}$ \\
\hline PCMB & $10^{-4}$ & 14 & \\
\hline MIA & $10^{-3}$ & 83 & -30 \\
\hline $\mathrm{NaN}_{3}$ & $10^{-3}$ & 80 & 65 \\
\hline $\mathrm{KCN}$ & $10^{-2}$ & 100 & 100 \\
\hline $\mathrm{KCN}$ & $10^{-3}$ & 95 & \\
\hline $\mathrm{KCN}$ & $10^{-4}$ & 58 & \\
\hline$o$-Phenanthroline & $2.5 \times 10^{-4}$ & 0 & \\
\hline $\mathrm{NH}_{2} \mathrm{OH}$ & $10^{-3}$ & 90 & 65 \\
\hline Acriflavin & $10^{-3}$ & 0 & \\
\hline Chlorpromazine & $10^{-3}$ & 0 & \\
\hline Nitrate & $10^{-3}$ & 0 & \\
\hline
\end{tabular}

Condition: $\mathrm{M} / 20$ phosphate buffer, $\mathrm{pH} 7.0 ; \mathrm{M} / 50$ substrate ; $10^{-2}-10^{-4} \mathrm{M}$ inhibitors ; $2-3 \mathrm{mg}$ dry weight of bacterial cells; $30^{\circ}$. PCMB : p-chloromercuribenzoate, MIA : monoiodoacetate. 
impermeable against bacterial cells or are not actually oxidized because of the lack of the oxidizing enzyme in the bacteria is not yet solved. To solve the problem, further examinations with cell-free extracts are necessary.

Exhaustive incubation of "Pink" cells with oxalate or formate led to an uptake of $2.5 \mu$ moles of oxygen per $10 \mu$ moles of oxalate or formate. Since 0.5 mole of

Table 3. Oxidative activities for various substrates by " Pink" cells.

\begin{tabular}{l|r||l|r}
\hline \hline \multicolumn{1}{c|}{ Substrates } & $\mathrm{Qo}_{2}$ & Substrates & $\mathrm{Qo}_{2}$ \\
\cline { 2 - 3 } Acetate & 91 & Glycine & 50 \\
Citrate & 25 & Alanine & 0 \\
iso-Citrate & 9 & Aspartate & 42 \\
$\alpha$-Ketoglutarate & 49 & Glutamate & 45 \\
Succinate & 139 & Glucose & 0 \\
Fumarate & 98 & Lactose & 6 \\
Malate & 96 & Ethanol & \\
Oxaloacetate & 138 & & \\
Pyruvate & 95 & & \\
Malonate & 16 & & \\
Propionate & 36 & & \\
Glycolate & 27 & & \\
\hline
\end{tabular}

Condition: $\mathrm{M} / 20$ phosphate buffer, $\mathrm{pH} 7.0 ; \mathrm{M} / 50$ substrates; $2-3 \mathrm{mg}$ dry weight of bacterial cells ; $30^{\circ}$.

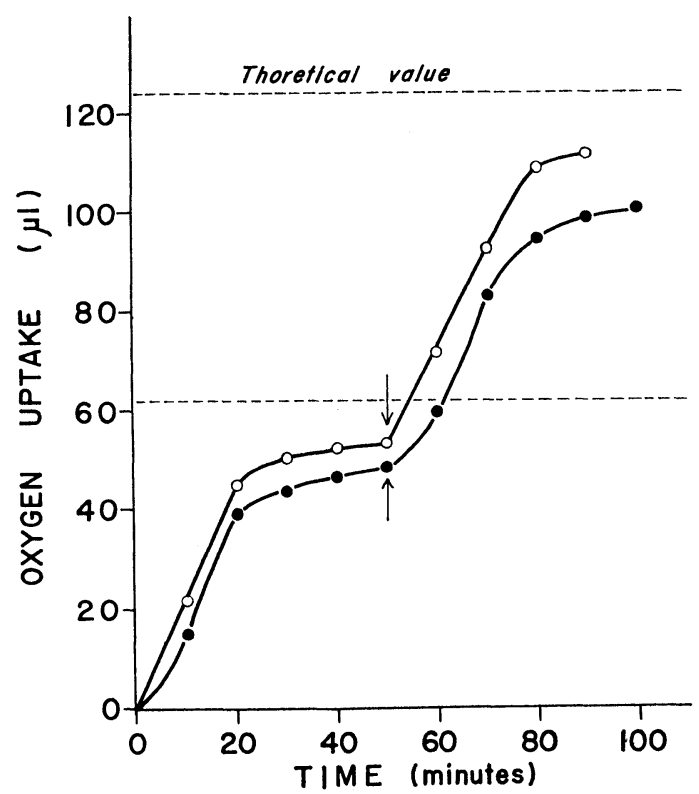

Fig. 2. Oxidation of oxalate and formate. $\mathrm{M} / 20$ phosphate buffer, $\mathrm{pH}$ $7.0 ; 30^{\circ}$. Ten $\mu$ moles of substrate was added at zero time, and at the arrow a further addition of $10 \mu$ moles of substrate was made. $\bigcirc-\bigcirc$ formate, 
oxygen is required for the complete combustion of 1 mole of oxalate or formate, oxygen consumed in the present experiment amounts to about one-half that required for complete combustion of oxalate or formate. Furthermore, the oxygen uptake increased immediately after addition of formate into the reaction mixture, while some time lag was observed when oxalate was added (Fig. 2).

Decomposition of oxalate was examined with the soluble enzyme system obtained.

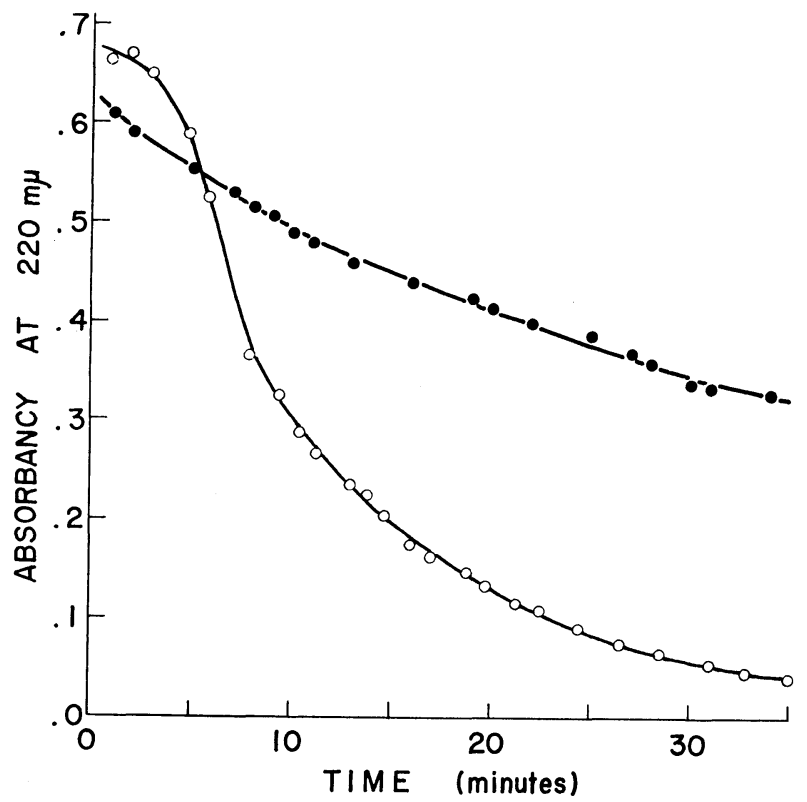

Fig. 3. Decomposition of oxalate by the soluble enzyme system obtained from "Pink" and "White" cells. The reaction mixture was composed of the following (expressed in $\mu$ moles) in a total volume of $30 \mathrm{ml}$ : : Tris buffer, $\mathrm{pH}$ 7.0, 150; potassium fluoride, 150 ; magnesium chloride, 15; glutathione, 15 ; acetate, 30 ; ATP, 15 ; CoA, 0.1 ; TPP, 0.15 ; oxalate, 3 . The reaction was started by the addition of the enzyme preparation to the reaction mixture at room temperature. $\bigcirc$, "Pink" cells; 0 , "White" cells.

Table 4. Oxidative activities of cells grown on different media.

\begin{tabular}{|c|c|c|c|c|c|}
\hline \multirow{2}{*}{$\begin{array}{l}\text { Sole carbon } \\
\text { source }\end{array}$} & \multirow{2}{*}{ Substrates } & \multicolumn{4}{|c|}{ Oxygen $(\mu \mathrm{M} / \mathrm{mg}$. dry wt/min.) } \\
\hline & & "Pink" & "Red" & "Yellow" & "White" \\
\hline \multirow{2}{*}{ Oxalate } & Oxalate & 9.3 & 12.9 & 8.5 & 56.6 \\
\hline & Formate & 37.5 & 55.8 & 17.5 & 54.3 \\
\hline \multirow{2}{*}{ Formate } & Oxalate & 3.6 & 2.6 & 0.4 & 13.1 \\
\hline & Formate & 13.5 & 42.1 & 16.2 & 37.9 \\
\hline \multirow{2}{*}{ Acetate } & Oxalate & 0.0 & \multirow{2}{*}{ No growth } & 0.0 & 10.7 \\
\hline & Formate & 67.2 & & 8.5 & 51.0 \\
\hline
\end{tabular}

Conditions: $\mathrm{M} / 20$ Tris buffer, optimum $\mathrm{pH}$ for each substrate (see Fig. 1) ; M/60 substrates; $2-3 \mathrm{mg}$ weight of bacterial cells; $30^{\circ}$. 


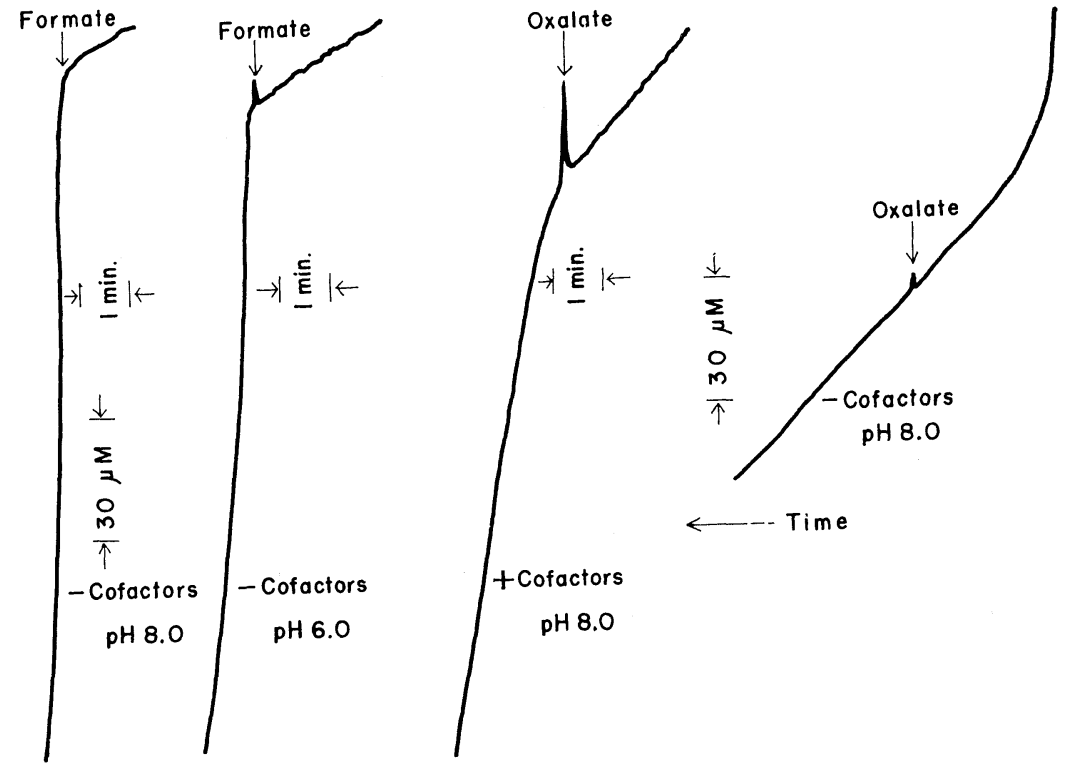

Fig. 4. Oxidation of oxalate by the soluble enzyme system obtained from "White" cells. Conditions are the same as in Fig. 3.

from "Pink" and "White" cells. Oxalate was decomposed by the supplementation of such incubation mixtures with ATP, CoA, TPP, $\mathrm{MgCl}_{2}$ and acetate. There was no reaction when these cofactors had been omitted from the reaction mixture (Fig. 3).

Only the reaction mixture with the cofactors showed rapid increase of oxygen uptake when oxalate was added. On the other hand, formate was more rapidly oxidized without the cofactors either at $\mathrm{pH} 6.0$ or 8.0. These data show that decarboxylation of oxalate required the cofactors (Fig. 4).

The oxidative activities of the cells grown on each of the three kinds of media, containing oxalate, formate or acetate, respectively, were examined with oxalate and formate as substrates. The rate of oxidation of oxalate by the bacteria grown on the oxalate medium was significantly higher than that in bacteria grown on formate or acetate (Table 4).

\section{Discussion}

The bacteria isolated in the present study are similar in general appearance and behavior to the bacteria previously isolated from soil by several authors ${ }^{2}$. The comparison between them will be described briefly, although the exact identity of the present bacteria has not been determined. "Red" closely resembles Bacterium extorquens $\mathrm{s}^{1)}$ especially in having a soluble red pigment, but the latter makes thin film in the liquid medium and the former does not. "Pink" makes thin film in the liquid medium, but it differs from $B$. extorquens in its content of pigment and preference of acidic medium. "Yellow" shows similar description to organism OD-1" of Jayasuria, except that the former is able to grow on a medium, in which formate or acetate is the sole carbon source, while the latter is not.

Soluble enzyme systems have been discovered which catabolize oxalic acid by three different routes, namely, oxidation, decarboxylation or activation followed by 
decarboxylation ${ }^{2}$. The optimum $\mathrm{pH}$ for oxidation of oxalate by the cell suspension of the four bacteria tested in the present study are 7.0 or 8.0 , while that of oxalate oxidizing enzymes extracted from mosses ${ }^{9)}$ and higher plants ${ }^{10)}$ is lower (about 5.0). The RQ values for the oxidation of oxalate by "Pink", "Red" and "Yellow" are 6,9 and 4, respectively. The former two values are by far larger than the theoretical value for complete oxidation of oxalate and thus indicate the concomitant occurrence of decarboxylating reaction. Although, it has been reported that the oxalic acid oxidase of moss plant is a flavin enzyme ${ }^{9}$, this does not seem to be the case in our bacterial enzyme, since the specific inhibitors for flavin enzymes did not affect the oxidation of oxalate by the "Pink" cells. Also, a similarity of the effects of the other inhibitors on oxalate and formate oxidation was revealed. From these data, it may be inferred that oxalate is not directly oxidized, but is decarboxylated first to give formate, as an intermediate, which is then oxidized.

This assumption was further confirmed by the experiments with enzyme preparations from "Pink" and "White". Oxalate decomposition by these organisms took place only when the cofactors which are thought to participate in activation of decarboxylation were added. Accordingly, in these bacteria, oxalate seemed to be catabolized through its decarboxylation to formate.

The experimental data of exhaustive incubation of oxalate in the presence of "Pink" cells indicate that some oxalate metabolism other than complete oxidation may occur at the same time. Increase of oxygen uptake did not start immediately after adding oxalate to the reaction mixture for "Rink" cells, but some time lag was needed. Similar but somewhat shorter time lag was also observed in the case of soluble enzyme system obtained from "White" cells in the presence of cofactors. This may also suggest that oxalate is decarboxylated to yield formate and then the latter is oxidized.

The oxalate-catabolizing system of these bacteria appears to be adaptive, since the oxalate-oxidizing rate by the bacteria cultured on oxalate medium was significantly greater compared with that of the cells grown on formate or acetate. The above evidence leads to the possibility that the bacteria which grow upon plants containing abundant oxalate might participate in scavenging oxalate in plant debris.

\section{References}

1) Bassalik, K., Jahrb. wiss. Botan. 53: 255 (1913).

2) Jakoby, W. B., and Bhat, J. V., Bacteriol. Rev. 22 : 75 (1958).

3) Kaneda, T., and Takamiya, A., J. Gen. Appl. Microbiol. 9: 223 (1963).

4) Bhat, J. V., and Barker, H. A., J. Bacteriol. $55: 359$ (1948).

5) Jakoby, W.B., Ohmura, E. K., and Hayaishi, O., J. Biol. Chem. 222: 435 (1956).
6) Shimazono, H., and Hayaishi, O., J. Biol. Chem. 227 : 151 (1957).

7) Frank, W., and Hase, K., Z. physiol. Chem. 249 : 231 (1937).

8) Jayasuria, G.C. N., J. Gen. Microbiol. 12 : 419 (1955).

9) Datta, P.K., and Meeuse, B. J. D., Biochim. Biophys. Acta 17: 602 (1955).

10) Finkle, B. J., and Arnon, D. I., Physiol. Plantarum 7 : 614 (1954). 
摘

要

屋良和子*·宇佐美正一郎**：三・三の細菌のシュウ酸分解について

クワズイモ (Alocasia macrorrhiza) の葉柄から, 桃色, 赤色, 黄色の三株のシュウ酸分解菌を分離し て，それらの菌懸濁液，無細胞抽出液を用いて，シュウ酸の代謝について調べた.

シュウ酸はまず, CoA, TPP, ATP などの補助因子の存在下で,脱炭酸されて後,酸化されると推察される. 呼吸実験で, 添加したシュウ酸は完全に反応液から消失するが，その際の酸素吸収量は添加したシュウ酸 の完全酸化の理論值の $1 / 2$ 量であった. 従って, 酸化と同時に他のシュウ酸代謝が行なわれているものと考 えられる.

また,これらの菌のシュウ酸分解系は，菌がシュウ酸の存在下で培養されることによって適応的に活性を 增す. (*琉球大学理工学部生物学科・**北海道大学理学部植物学教室) 